\title{
Croatian Translation and Validation of the Mind-Wandering Questionnaire (MWQ)
}

\author{
Marina Perković Kovačević
}

University Hospital Centre Osijek, Department of Psychiatry, Osijek, Croatia, J. J. Strossmayer University of Osijek, Faculty of Medicine, Department of Psychiatry and Psychological Medicine, Osijek, Croatia

\section{Mario Ćurković}

J. J. Strossmayer Univeristy of Osijek, Faculty of Medicine, Department of Family

Medicine, Osijek, Croatia

\section{Dražen Gorjanski}

Croatian Health Insurance Fund, Department of supervision and control, Osijek, Croatia

\author{
Ivon Matić
}

Health Centre Županja, Županja, Croatia

\begin{abstract}
This research aimed to translate and validate the Mind-Wandering Questionnaire (MWQ) to the Croatian language, and to provide preliminary data on its reliability, factor structure and convergent validity in a sample of Croatian students. After translation and adaptation, the Croatian version of the MWQ was administered to 451 eight-grade elementary school students (239 female and 212 male participants). With the MWQ, we administered the Emotional Skills and Competence Questionnaire (ESCQ-45). Results show high internal consistency of the Croatian translation of the MWQ. Confirmatory factor analysis supports an unidimensional model. Convergent validity was supported by a significant negative correlation between MWQ and Emotional Skills and Competence Questionnaire. We propose further investigation of psychometric properties of the Croatian translation of the MWQ and investigating test-retest reliability as well as discriminant validity of the Questionnaire.
\end{abstract}

Keywords: mind-wandering, validation, Croatian translation of the MWQ, students

Marina Perković Kovačević, J. J. Strossmayer University of Osijek, Faculty of Medicine, Department of Psychiatry and Psychological Medicine, Fourth Josip Huttler St., 31000 Osijek, Croatia. E-mail: marina.perkovic@gmail.com

\section{Acknowledgment}

We would like to express our deep gratitude to the Administrative Department for Social Affairs of the City of Osijek for its organization and technical support in conducting this research. 


\section{Introduction}

This research aimed to translate and validate the Mind-Wandering Questionnaire (MWQ) to the Croatian language. Mind-wandering is a mental phenomenon in which executive control shifts from the primary task to the processing of personal goals (Smallwood \& Schooler, 2006). This particular kind of thoughts can be defined as stimulus-independent and task-unrelated thoughts, in the sense that their content $a$ ) is not the direct reflection of current sensory input and $b$ ) is unrelated to the task being performed at the moment of their occurrence (Stawarczyk et al., 2011a, 2011b). It is one of the ubiquitous and pervasive of all the cognitive phenomena (Schooler et al., 2014; Smallwood \& Schooler, 2006; Song \& Wang, 2012) and occurs during $30-50 \%$ of our daily waking state (Kane et al., 2007; Killingsworth \& Gilbert, 2010). Mind-wandering is often elicited by external or internal cues rather than emerging out of nowhere (Song \& Wang, 2012). The frequency of mind-wandering is influenced by several factors, such as attention orientation, devotion to the task, and mood (Song \& Wang, 2012).

Ubiquity, high frequency of appearance and especially the contents of mindwandering indicate its importance. Most of the thoughts during mind-wandering are self-related (Baird et al., 2011; Smallwood et al., 2011), mainly oriented toward the future (Smallwood et al., 2009) and the upcoming events (Baird et al., 2011; Stawarczyk et al., 2011b). In addition, by keeping the thoughts of the past in our memories, mind-wandering enables us to maintain self-awareness (Tulving, 1987).

Studies also suggest that mind-wandering could enhance creativity. For instance, individuals with Attention-Deficit/Hyperactivity Disorder (ADHD) score higher on measures of creativity (White \& Shah, 2006) than individuals without ADHD. Constant attachment to the problem can impede creativity while interruption can increase it (Dijksterhuis \& Meurs, 2006). Meta-analysis of the conditions that maximize incubation effects (problem-solving by temporarily giving up), found that the benefits of incubation intervals are greater when individuals are occupied by low cognitive demand task compared to when they engage in either a high-demanding task or no task at all (Sio \& Ormerod, 2009).

Unfortunately, mind-wandering is a double-edged sword. Despite its obvious usefulness, it is associated with many difficulties. These include: 1) reduced reading comprehension, (McVay \& Kane, 2012; Smallwood et al., 2011); 2) impaired driving (He et al., 2011); 3) having trouble paying attention during lectures (Lindquist \& McLean, 2011; Risko et al., 2012) and 4) reduced scores on memory tasks (Smallwood et al., 2003). High levels of mind-wandering are also associated with less life satisfaction (Mar et al., 2012), increased depressive symptomatology (Smallwood et al., 2007; Watts et al., 1988), worse mood, greater stress, lower selfesteem (Mrazek et al., 2013), and more negative thinking (Smallwood et al., 2007). Although the mode of operation is not entirely clear, some mental disciplines, 
especially mindfulness meditation, reduce wandering of the mind and its negative consequences (Bakosh et al., 2015; Xu et al., 2014).

In a large online study, conducted among men and women in the general population, aged 16 to 83, with or without ADHD, men without ADHD had higher scores on mind-wandering (Mowlem et al., 2019). At the same time, research of primary school students in the temporal focus during spontaneous mental time travel in daily life, revealed that the average score in the past orientation and future orientation respectively had no main effect of gender or grade (Ye et al., 2014).

There are two categories and four main methods for measuring mindwandering. The first category is the objective/indirect. It includes measurements of 1) reaction time or 2) eye movements and other physiological measures. The second category includes two subjective/direct methods that use self-caught measures, in which participants report whenever they notice their minds have wandered, and probe-caught measures, in which participants are intermittently probed and asked whether at that particular time they were mind-wandering (Weinstein, 2018).

Among the questionnaires that have been used to assess mind-wandering, the most common are: 1) Daydream Frequency Scale (DDFS), also known as the Daydream Subscale of the Imaginal Process Inventory (Giambra, 1995) that predominantly refers to stimulus-independent thoughts; 2) Attention Related Cognitive Errors Scale (ARCES) (Cheyne et al., 2006) that primarily considers the frequency of everyday mistakes; 3) Mindful Attention and Awareness Scale (MAAS) (Brown \& Ryan, 2003) that measures awareness of what is occurring in the present; 4) The Mind Excessively Wandering Scale (MEWS) (Mowlem et al., 2016) that was created primarily to determine the ADHD symptoms; and 5) Mind-Wandering Questionnaire (MWQ) (Mrazek et al., 2013) that measures the frequency of mindwandering irrespective of whether it is deliberate or spontaneous.

Although the DDFS is widely used as a measure of mind-wandering, this questionnaire is focused more on stimulus-independent thoughts than on taskunrelated thoughts. The key difference between the constructs of daydreaming and mind-wandering relates to the relevance of a primary task from which the attention is diverted. Daydreaming refers to stimulus-independent thought that does not occur during a primary task, while mind-wandering means a shift of attention away from a task (Mrazek et al., 2013). According to the authors, "MWQ is a suitable tool for researchers to use when they are specifically interested in mind-wandering, as opposed to related constructs assessed by the DDFS, ARCES, or MAAS“ (Mrazek et al., 2013, p. 5).

Mind-wandering with a consequent lack of attention represents a particular problem when transferring knowledge to students, whether it is during the traditional classroom teaching (Bunce et al., 2010) or online education (Szpunar et al., 2013). The results of previous research suggest a significant correlation of attention regulation difficulties with emotional knowledge. Emotional knowledge comprises many aspects, such as understanding the functions of emotions, emotion activators 
as well as the rules for displaying emotions (Izard, 2001). Children who can process noticeable emotional cues in the educational environment are more likely to carry out academic tasks. On the other hand, children whose emotional knowledge is low might have more strained relationships and more unpleasant encounters with their teachers and peers, and, consequently, have problems directing their attention and concentrate on academic tasks (Izard et al., 2001). Furthermore, developmental theory suggests that processes of attention and emotion overlap when it comes to neural circuitry and are interconnected from early childhood onward (Greenberg \& Snell, 1997; Kopp, 2002). In other words, children regulate emotions using attention, and the way they experience emotions affects their ability to respond to stimuli. Their attention is often captured by stimuli that evoke emotion, which may affect the children's emotional experience in terms of its type and intensity (Greenberg \& Snell, 1997). Moreover, the leading research model for investigating regulation of emotions often uses measuring of attention shift and focus as an indicator of regulation ability (Eisenberg et al., 2001). Therefore, attentional and emotional competence potentially correlate in the academic environment, which is worthy of empirical investigation (Mostow \& Fine, 2006). To solve this problem, various practical strategies have been devised: integration of "checkpoint" questions throughout lectures and active learning through demonstrations, discussions, or other activities to allow students to mind-wander when it will not significantly affect learning (Pachai et al., 2016). An additional strategy focuses on interpolating memory tests while viewing on-line lectures (Szapunar et al., 2013).

If we want to explore the impact of these, or some future techniques, on mindwandering and improving students' abilities, it is essential to have a reliable instrument for measuring the wandering of the mind. As the MWQ is short (contains only 5 items), designed for undergraduate, high-school and middle-school students and directly measures mind-wandering trait levels, we considered it as the most appropriate for translation and adaptation into the Croatian language. Mrazek et al. (2013) reported factorial analyses of the MWQ, proposing a single-factor solution with internal consistency measured by Cronbach Alpha of .85 .

Previously, the MWQ was translated and validated in Spain (Salavera et al., 2017), China (Luo et al., 2016) and Japan (Kajimura \& Nomura, 2016) and a singlefactor solution was confirmed in these studies. As there is no Croatian scale for mindwandering, translation and validation of the MWQ into the Croatian will enable the study of this phenomenon in the Croatian students. Given the fact that previous research has shown a significant correlation between emotional competence and attention processes in children, which underlies the process of mind-wandering (Mostow \& Fine, 2006), we decided to examine the association of emotional competence with mind-wandering to determine convergent validity. 


\section{Method}

\section{Participants and Procedure}

In our study, participants were eight-grade elementary school students. Students were recruited from 20 elementary schools in the city of Osijek. Before starting the study, we contacted the Administrative Department for Social Affairs of the City of Osijek to inform them of our research and to obtain permission to conduct the research. After obtaining the permission, the city authorities informed all of the 20 elementary school principals about our research and asked them to help us with the testing of children. In the next step, we visited the schools and verbally informed each principal, pedagogue and psychologist at the school, and provided them with forms for informed parental consent and tests for children. After obtaining the signed consent forms from the parents, the children were tested. The study was conducted between April and May 2019. The Emotional Skills and Competence Questionnaire (ESCQ-45; Takšić, 1998) was administered with the MWQ. Out of the 869 students in all of the 20 elementary schools in Osijek, 451 (239 female and 212 male) completed the questionnaire, representing a response rate of $52 \%$. The average student age was $14.2(S D=0.45$; range from 13 to $16, M d n=14)$. The study was conducted with the full cooperation of the parents of the students who participated in the study, with their appropriate understanding of the implementation of the research, and has therefore been performed in accordance with the ethical standards laid down in the Declaration of Helsinki (1964).

\section{Measures}

The Mind-Wandering Questionnaire is a five-item, self-assessing questionnaire, which rates trait levels of mind-wandering (Mrazek et al., 2013). Items are rated on a 6-point scale ranged from 1 (Almost never) to 6 (Almost always). Items include statements such as "I have difficulty maintaining focus on simple or repetitive work" and "While reading, I find I have not been thinking about the text and must therefore read it again". The total score for the mind-wandering questionnaire for all five items can range from 5 to 30 . After obtaining permission to use the Mind-Wandering Questionnaire from the author of the original questionnaire, we had the questionnaire translated into Croatian by three bilingual experts using the back-translation method. The initial translation of the MWQ from English to Croatian was performed independently by three translators whose mother tongue was Croatian. In the next step, the translations were compared and all the different translation options were discussed. As a result, the researchers constructed a unique version containing the items for which they all agreed they represent the best semantic and conceptual translation of the original items, as well the best one in terms of clarity, common language, and cultural adequacy. The final Croatian version of translation was then translated from Croatian into English (back-translation) by one 
researcher with proficiency in both English language and mind-wandering research. In this study, the Cronbach's alpha for the whole questionnaire was .82.

Emotional competence was measured by the Emotional Skills and Competence Questionnaire, ESCQ-45 (Takšić, 1998). The term "emotional competence" was chosen because it equally emphasizes the importance of emotional competence in person's daily adjustment, but also because of the prevailing view that only intelligence can be measured by the aptitude tests. It is constructed according to the emotional intelligence model of Mayer and Salovey, which differs between the perception and expression of emotions, and which is presented in separate dimensions. The questionnaire is intended to assess emotional competence, the process of recognizing one's own and others' emotional states in order to solve problems more effectively and regulate behaviour more appropriately. It consists of 45 items arranged in three subscales: Perceiving and understanding emotions, Expressing and labelling emotions, and Managing and regulating emotions.

The subjects respond to each of the statements by a degree of agreement on a 5point scale, from 1 (Not at all) to 5 (Entirely yes), and the corresponding points are summed within the scales. The psychometric characteristics of the ESCQ-45 are generally good, so the reliability of the whole questionnaire in different samples is from .88 to .92 (Takšić \& Smojver-Ažić, 2016). In this study, the Cronbach's alpha for the whole questionnaire was .90 .

Correlation between individual subscales ranges from .35 to .51 , so the overall score can be formed as a measure of general emotional competence, with reliability between .87 and .92. (Takšić et al., 2006). In this study, the correlations between individual subscales range from .43 to .48 , which justifies the use of the total score as a measure of emotional competence.

\section{Statistical Analysis}

Data were analyzed using the Statistical Package for Social Sciences (SPSS) for Windows, version 21 (IBM Corp., 2012). All the tests were two-tailed and conducted at the $5 \%$ level of statistical significance. Pearson's correlation coefficient was used to calculate the correlations between the Croatian translation of the MWQ and the Emotional Skills and Competence Questionnaire.

We conducted the confirmatory factor analysis (CFA) by Mpus 7.1 to examine the unidimensional factor structure of the questionnaire with the weighted least square mean and variance adjusted (WLSMV) method for ordinal indicators. As model fit indices, we used: (a) WLSMV chi-square $\left(\chi^{2}\right)$ (Muthén \& Muthén, 2012), and the ratio of chi-square and degrees of freedom $\left(\chi^{2} / d f\right)$, where the ratio between 2 and 5 indicate a good model fit (Marsh \& Hocevar, 1985); (b) the root mean squared error of approximation (RMSEA; Steiger, 2000), where values of $<.05$ were taken as a good fit, and .05 - .08 as a moderate fit; (c) the comparative fit index (CFI) where values of .90 were taken as an adequate fit, $.90-.95$ as a moderate fit and below .95 
as a perfect fit (Hu \& Bentler, 1999) and standardized root mean square residual (SRMR) with $<.08$ indicated a good fit (Steiger, 2000).

Omega reliability coefficient was calculated using the JASP program (Version 0.12; JASP Team, 2020).

\section{Results}

\section{Descriptive Statistics}

Mean result on the Croatian version of the MWQ was $17.80(S D=5.26)$. Modal value was 15 , with 37 participants achieving this result. Distribution doesn't differ from normal with Skewness $=.05($ S.E. $=0.11)$ and Kurtosis $=-.65($ S.E. $=0.23)$. According to Field (2005), asymmetry index and curvature coefficient should be equal to or close to zero to confirm normal distribution. Although the above results differ from zero, the results can be viewed as acceptable, since Kline (2011) states that the criteria for normal distribution are absolute values of asymmetry and curvature. The absolute value of asymmetry should be less than 3 and the absolute value of curvature less than 8 . Since the above results correspond to that, the implementation of parametric procedures can be continued.

Internal consistency was measured with Cronbach's Alpha and it was .82 with all 5 items. Mean inter-item correlation was .48. (Table 1).

The mean result on the Emotional Skills and Competence Questionnaire was $M$ $=157.42, S D=19.22$. Distribution does not differ from normal with Skewness = $-.33($ S.E. $=.11)$ and Kurtosis $=.09($ S.E. $=.23)$. Internal consistency was measured with Cronbach's Alpha and it was .90 . Mean inter-item correlation was .28 with minimum value .32 and maximum .64 .

Table 1

Descriptive Statistics and Reliability for MWQ and ESCQ-45

\begin{tabular}{lcc}
\hline & MWQ & ESCQ-45 \\
\hline$S D$ & 17.80 & 157.42 \\
\hline Median & 5.26 & 19.22 \\
\hline Mode & 18 & 159 \\
\hline Min-max & 15 & 169 \\
\hline Skewnes & $5-30$ & $90-207$ \\
\hline Std. Error of Skewnes & 0.05 & -0.33 \\
\hline Kurtosis & 0.11 & 0.11 \\
\hline Std. Error of Kurtosis & -0.65 & 0.09 \\
\hline Mean inter-item correlation & 0.23 & 0.23 \\
\hline Cronbach a & .48 & .28 \\
\hline
\end{tabular}

Note. MWQ - Mind-Wandering Questionnaire; ESCQ-45 - Emotional Skills and Competence Questionnaire. 


\section{Factorial Analysis of the Croatian Translation of the MWQ}

The CFA confirmed the unidimensional factor structure of the questionnaire since all goodness of fit indices were above critical values $\left(\chi^{2}(4)=11.22, d f=4 ; p=\right.$ $.024 ; \chi^{2} / d f=2.80 ; \mathrm{CFI}=.991 ; \mathrm{RMSEA}=.063$ (90\% confidence interval $\left..021-.109\right)$. and SRMR $=.023$. Also, all the items significantly loaded the factor, with factor loadings ranging from .47 to .84 . (Table 2 ). We also calculated the omega reliability coefficient, which is .83 .

Table 2

Factor Loadings of the Confirmatory Factor Analysis (CFA) of the Unidimensional Model of the $M W Q$

\begin{tabular}{lc}
\hline Items & $F$ \\
\hline $\begin{array}{l}\text { 1. I have difficulty maintaining focus on simple or repetitive work. } \\
\text { [Teško se koncentriram na jednostavne ili jednolične zadatke.] }\end{array}$ & .47 \\
\hline $\begin{array}{l}\text { 2. While reading, I find I haven't been thinking about the text and must } \\
\text { therefore read it again. }\end{array}$ & .66 \\
$\quad$ [Tijekom čitanja događa se da ne razmišljam o tekstu te ga stoga moram \\
ponovno pročitati.]
\end{tabular}

\section{Correlations between MWQ and ESCQ-45}

To analyze the convergent validity of the MWQ, we calculated the correlation between the MWQ and self-reported measure of emotional competence (ESCQ-45). Since distribution of the MWQ and emotional competence scores did not differ from normal, we proceeded with parametric correlation analysis. Pearson's correlation coefficient between the MWQ and emotional competence was $r=-.28, p=.000$, pointing to a weak but significant negative relation between these variables.

\section{Discussion}

The purpose of this study was to adapt a Croatian version of the MWQ (Mrazek et al., 2013), which would allow comparability with the results from other countries. Furthermore, it would provide researchers in Croatia with a mind-wandering 
measure for adolescents with or without specific disorders, such as attention deficit disorder, specific learning difficulties etc. This measure would be useful in school practice, as well as for scientific purposes. Our results revealed that the Croatian version of MWQ for adolescents evidences high construct validity and reliability.

\section{Reliability and Factor Structure of the Croatian Translation of the MWQ}

As for internal consistency of the Croatian version of the MWQ, Chronbach's Alpha was .82 among the 5 items, which points to good reliability. To further test the internal consistency, we next examined the inter-item correlations. The results showed positive and significant results among items of the MWQ, with values similar to those obtained by Mrazek (Mrazek et al., 2013). Consistently moderate inter-item correlations are preferred, as they show good internal reliability without highly redundant (expendable) items (Clark \& Watson, 1995). According to these criteria, the MWQ had moderate inter-item correlations.

The factorial structure of the MWQ was analyzed by a confirmatory factorial analysis. The results of the confirmatory factorial analysis indicated that the model is fitted to the data, which confirmed the one scale's dimensional structure and corresponded with both the initial questionnaire postulates (Mrazek et al., 2013) and the factorial structure seen in the original questionnaire version, as well as in the results of confirmatory factorial analysis of the questionnaire in Spanish, Chinese and Japanese (Luo et al., 2016; Kajimura \& Nomura, 2016; Salavera et al., 2017). Our results point to the appropriateness of using the Croatian translation of MWQ with adolescents.

\section{Convergent Validity}

Convergent validity of the Croatian translation of the MWQ was evaluated by investigating correlations with the self-reported measure of emotional competence (measured by the Emotional Skills and Competence Questionnaire; Takšić, 1998). To the best of our knowledge, ESCQ was not used previously to test the convergent validity of MWQ. Whereas previous research has shown a significant correlation between emotional competence and attention processes in children, which underlie the process of mind-wandering (Mostow \& Fine, 2006), we decided to use emotional competence to test convergent validity.

In our research, we found a week but significant negative relation between MWQ and emotional competence, supporting the convergent validity of the Croatian translation of the MWQ. Such data are consistent with developmental theories and research that suggest that attention and emotional processes have overlapping neural activities (Greenberg \& Snell, 1997; Kopp, 2002). 


\section{Limitations of the Study}

This study should be evaluated with certain important limitations in mind. All the participants in the study are elementary school students, due to which the findings of the study may not be generalizable for adults. We did not investigate whether there are gender differences, what their impact is on mind-wandering, and what effect gender has on mind-wandering. To determine the impact of gender on mindwandering we believe we should use a sample of children in the lower and upper grades of primary school as well as children in rural and urban areas. In future studies we should also make an in-depth examination of how can mind-wandering influence performance and different subjective well-being components (subjective happiness, self-esteem, satisfaction with life), like in other studies (Kajimura \& Nomura, 2016; Luo et al., 2016; Salavera et al., 2017). In addition, since numerous research opportunities are opening up in this area, we plan to include covariates in our future work, such as gender, age, place of residence etc.

\section{Conclusion}

This paper presents the Croatian version of the Mind-Wandering questionnaire. Our data point to good reliability of the Croatian translation of the MWQ based on the internal consistency coefficient. Furthermore, the result of the CFA indicated that unidimensional structure fitted the data well and corresponded with both the initial questionnaire postulates and the factorial structure seen in the original questionnaire version. Convergent validity was supported by a significant negative correlation between the MWQ and emotional competence. In addition, this questionnaire could be useful for indirect measurement of the effectiveness of interventions such as mindfulness-based program and mindfulness-based cognitive therapy, adapted for children, which reduce MW helping the adolescent to improve academic performance.

\section{References}

Baird, B., Smallwood, J., \& Schooler, J. W. (2011). Back to the future: Autobiographical planning and the functionality of mind-wandering. Consciousness and Cognition, 20, 1604-1611.

Bakosh, L. S., Snoiv, R. M., Tobias, J. M., Houlihan, J. L., \& Barbosa-Leiker, C. (2015). Maximizing mindful learning: Mindful awareness intervention improves elementary school students' quarterly grades. Mindfulness, 7, 59-67.

Brown, K. W., \& Ryan, R. M. (2003). The benefits of being present: Mind-fulness and its role in psychological well-being. Journal of Personality and Social Psychology, 84, 822-848. 
Bunce, D. M., Flens, E. A., \& Neiles, K. Y. (2010). How long can students pay attention in class? A study of student attention decline using clickers. Journal of Chemical Education, 87, 1438-1443.

Cheyne, J. A., Carriere, J. S. A., \& Smilek, D. (2006). Absent-mindedness: Lapses of conscious awareness and everyday cognitive failures. Consciousness and Cognition, 15, 578-592.

Clark, L., \& Watson, D. (1995). Constructing validity: Basic issues in objective scale development. Psychological Assessment, 7(3), 309-319. https://doi.org/10.1037/10403590.7.3.309

Dijksterhuis, A., \& Meurs, T. (2006). Where creativity resides: The generative power of unconscious thought. Consciousness and Cognition, 15, 135-146.

Eisenberg, N., Cumberland, A., Spinrad, T. L., Fabes, R. A., Shepard, S. A., Reiser, M., Murphy, B. C., Losoya, S. H., \& Guthrie, I. K. (2001). The relations of regulation and emotionality to children's externalizing and internalizing problem behavior. Child Development, 72, 1112-1134.

Field, A. (2005). Discovering statistics using SPSS (2nd ed.). Sage Publications, Inc.

Giambra, L. M. (1995). A laboratory method for investigating influences on switching attention to task-unrelated imagery and thought. Consciousness and Cognition, 4, 1-21. https://doi.org/10.1006/ccog.1995.1001

Greenberg, M. T., \& Snell, J. (1997). Brain development and emotional development: The role of teaching in organizing the frontal lobe. In P. Salovey \& D. Sluyter (Eds.), Emotional development and emotional intelligence: Educational implications (pp. 93119). Basic Books.

He, J., Becic, E., Lee, Y. C., \& Mccarley, J. S. (2011). Mind wandering behind the wheel: Performance and oculomotor correlates. Human Factors, 53, 13-21.

Hu, L. T., \& Bentler, P. M. (1999). Cutoff criteria for fit indexes in covariance structure analysis: Conventional criteria versus new alternatives. Structural Equation Modeling: A Multidisciplinary Journal, 6(1), 1-55. https://doi.org/10.1080/10705519909540118

Izard, C. E. (2001). Emotional intelligence or adaptive emotions? Emotion, 1, 249-257.

Izard, C., Fine, S., Schultz, D., Mostow, A., Ackerman, B., \& Youngstrom, E. (2001). Emotion knowledge as a predictor of social behavior and academic competence in children at risk. Psychological Science, 12, 18-23.

JASP Team (2020). JASP (Version 0.13.1). [Computer software].

Kajimura, S., \& Nomura, M. (2016). Development of Japanese versions of the daydream frequency scale and the mind wandering questionnaire. Shinrigaku Kenkyu: The Japanese Journal of Psychology, 87(1), 79-88.

Kane, M. J., Brown, L. H., McVay, J. C., Silvia, P. J., Myin-Germeys, I., \& Kwapil, T. R. (2007). For whom the mind wanders, and when: An experience-sampling study of working memory and executive control in daily life. Psychological Science, 18(7), 614 621. 
Killingsworth, M. A., \& Gilbert, D. T. (2010). A wandering mind is an unhappy mind. Science, 330(6006), 932-932.

Kline, P. (2011). The handbook of psychological testing (2nd ed.). Routledge.

Kopp, C. B. (2002). Commentary: The codevelopments of attention and emotion regulation. Infancy, 3, 199-208.

Lindquist, S. I., \& McLean, J. P. (2011). Daydreaming and its correlates in an educational environment. Learning and Individual Differences, 21, 158-167.

Luo, Y., Zhu, R., Ju, E., \& You, X. (2016). Validation of the Chinese version of the MindWandering Questionnaire (MWQ) and the mediating role of self-esteem in the relationship between mind-wandering and life satisfaction for adolescents. Personality and Individual Differences, 92, 118-122.

Mar, R. A., Mason, M. F., \& Litvack, A. (2012). How daydreaming relates to life satisfaction, loneliness, and social support: The importance of gender and daydream content. Consciousness and Cognition, 21, 401-407.

Marsh, H. W., \& Hocevar, D. (1985). Application of confirmatory factor analysis to the study of self-concept: First-and higher order factor models and their invariance across groups. Psychological Bulletin, 97(3), 562-582.

McVay, J. C., \& Kane, M. J. (2012). Why does working memory capacity predict variation in reading comprehension? On the influence of mind wandering and executive attention. Journal of Experimental Psychology: General, 141, 302-320.

Mostow, A. J., \& Fine, S. E. (2006). Children's emotional competence and attentional competence in early elementary school. School Psychology Quarterly, 21(2), 148-170.

Mowlem F. D., Agnew-Blais J., Jean-Baptiste Pingault J., \& Asherson P. (2019) Evaluating a scale of excessive mind wandering among males and females with and without attention-deficit/hyperactivity disorder from a population sample. International Journal of Scientific Reports, 9(1), 3071.

Mowlem, F. D., Skirrow C., Reid P., Maltezos S., Mijjar S., Merwood A., Barker E., Cooper R., Kuntsi J., \& Asherson P. (2016). Validation of the Mind Excessively Wandering Scale and the relationship of mind wandering to impairment in adult ADHD. Journal of Attention Disorders, 23(6), 624-634.

Mrazek, M. D., Phillips, D. T., Franklin, M. S., Broadway, J. M., \& Schooler, J. W. (2013). Young and restless: Validation of the Mind-Wandering Questionnaire (MWQ) reveals disruptive impact of mind-wandering for youth. Frontiers in Psychology, 4, 560.

Muthén, L. K., \& Muthén, B. O. (2012). Mplus user's guide (7th ed.). Muthén \& Muthén.

Pachai, A. A., Acai, A., LoGiudice, A. B., \& Kim, J. A. (2016). The mind that wanders: Challenges and potential benefits of mind wandering in education. Scholarship of Teaching and Learning in Psychology, 2(2), 134-146.

Risko, E. F., Anderson, N., Sarwal, A., Engelhardt, M., \& Kingstone, A. (2012). Everyday attention: Variation in mind wandering and memory in a lecture. Applied Cognitive Psychology, 26, 234-242. 
Salavera, C., Urcola-Pardo, F., Usán, P., \& Jarie, L. (2017). Translation and validation of the Mind-Wandering Test for Spanish adolescents. Psicologia Reflexão e Crítica. 30(1), 12. https://doi.org/10.1186/s41155-017-0066-8

Schooler, J. W., Mrazek, M. D., Franklin, M. S., Baird, B., Mooneyham, B. W., Zedelius, C., \& Broadway, J. M. (2014). The middle way: Finding the balance between mindfulness and mind-wandering. In B. H. Ross (Ed.), The psychology of learning and motivation (Vol. 60, pp. 1-33). Academic Press.

Sio, U. N., \& Ormerod, T. C. (2009). Does incubation enhance problem solving? A metaanalytic review. Psychological Bulletin, 135, 94-120.

Smallwood, J., Baracaia, S. F., Lowe, M., \& Obonsawin, M. (2003). Task unrelated thought whilst encoding information. Consciousness and Cognition, 12, 452-484.

Smallwood, J., Nind, L., \& O'Connor, R. C. (2009). When is your head at? An exploration of the factors associated with the temporal focus of the wandering mind. Consciousness and Cognition, 18(1), 118-125.

Smallwood, J., O’Connor, R. C., Sudbery, M. V., \& Obonsawin, M. (2007). Mind wandering and dysphoria. Cognition and Emotion, 21(4), 816-842.

Smallwood, J., \& Schooler, J. W. (2006). The restless mind. Psychological Bulletin, 132(6), 946-958. https://doi.org/10.1037/0033-2909.132.6.946

Smallwood, J., Schooler, J. W., Turk, D. J., Cunningham, S. J., Burns, P., \& Macrae, C. N. (2011). Self-reflection and the temporal focus of the wandering mind. Consciousness and Cognition, 20, 1120-1126.

Song, X., \& Wang, X. (2012). Mind wandering in Chinese daily lives-an experience sampling study. PLOS ONE, 7(9), e44423.

Stawarczyk, D., Majerus, S., Maquet, P., \& D’Argembeau, A. (2011a). Neural correlates of ongoing conscious experience: Both task-unrelatedness and stimulus-independence are related to default network activity. PLOS ONE 6, e16997. https://doi:10.1371/journal. pone.0016997

Stawarczyk, D., Majerus, S., Maj, M., Van der Linden, M., \& D’Argembeau, A. (2011b). Mind- wandering: Phenomenology and function as assessed with a novel experience sampling method. Acta Psychologica, 136, 370-381.

Steiger, J. H. (2000). Point estimation, hypothesis testing, and interval estimation using the RMSEA: Some comments and a reply to Hayduk and Glaser. Structural Equation Modeling, 7(2), 149-162. https://dx.doi.org/10.1207/S15328007SEM0702_1

Szapunar, K. K., Khan N. Y., \& Schster D. L. (2013). Interpolated memory tests reduce mind wandering and improve learning of online lectures. PNAS, 110(16), 6313-6317.

Takšić, V., Mohorić, T., \& Munjas, R. (2006). Emocionalna inteligencija: Teorija, operacionalizacija, primjena i povezanost $\mathrm{s}$ pozitivnom psihologijom [Emotional intelligence: Theory, operationalization, application and connection with positive psychology]. Drušvena istraživanja, 84-85(4-5), 729-752. 
Takšić, V., \& Smojver-Ažić, S. (2016). Promocija zdravlja razvojem socio-emocionalnih $i$ kompetencija $u$ školskom okruženju [Health promotion through the development of socio-emotional and competencies in the school environment]. Katedra za socijalnu medicinu i epidemiologiju, Medicinski fakultet Sveučilišta u Rijeci.

Takšić, V. (1998). Validacija konstrukta emocionalne inteligencije [Validation of the construct of emotional intelligence]. [Unbubslihed doctoral dissertation]. Faculty of Humanities and Social Sciences, University of Zagreb.

Tulving, E. (1987). Multiple memory systems and consciousness. Human neurobiology, 6, 67-80.

Watts, F. N., Macleod, A. K., \& Morris, L. (1988). Associations between phenomenal and objective aspects of concentration problems in depressed patients. British Journal of Psychology, 79, 241-250.

Weinstein, Y. (2018). Mind-wandering, how do I measure thee with probes? Let me count the ways. Behavior Research Methods, 50, 642-661.

White, H. A., \& Shah, P. (2006). Uninhibited imaginations: Creativity in adults with attention deficit/hyperactivity disorder. Personality and Individual Differences, 40, 1121-1131.

Xu J., Vik A., Groote I. R., Lagopoulos J., Holen A., Ellingsen Ø., Håberg A. K., \& Davanger S. (2014). Nondirective meditation activates default mode network and areas associated with memory retrieval and emotional processing. Frontiers in Human Neuroscience, 8 , 86. https://doi.org/10.3389/fnhum.2014.00086

Ye, Q., Song, X., Zhang, Y., \& Wang, Q. (2014). Children's mental time travel during mind wandering. Frontiers in Psychology, 5, 927. https://doi.org/10.3389/fpsyg.2014.00927

\title{
Prijevod i validacija Upitnika lutanja uma (MWQ)
}

\begin{abstract}
Sažetak
Cilj je ovoga istraživanja bio prijevod i validacija Upitnika lutanja uma (engl. Mind Wandering Questionnaire, MWQ) na hrvatski jezik te predstavljanje preliminarnih podataka o njegovoj pouzdanosti, strukturi i konvergentnoj valjanosti na uzorku hrvatskih učenika. Nakon prevođenja i prilagodbe hrvatski je prijevod MWQ-a primijenjen na 451 učeniku osmih razreda osnovne škole (239 djevojčica i 212 dječaka). Usporedno s MWQ-om primijenjen je i Upitnik emocionalne kompetentnosti (ESCQ-45). Rezultati pokazuju visoku pouzdanost hrvatskoga prijevoda MWQ-a, dok je konfirmatornom faktorskom analizom potvrđen jednodimenzionalni model. Značajna negativna korelacija MWQ-a i Upitnika emocionalne kompetentnosti upućuje na dobru konvergentnu valjanost hrvatskoga prijevoda upitnika. Daljnjim istraživanjima potrebno je dodatno provjeriti psihometrijska svojstva hrvatskoga prijevoda MWQ-a, posebno test-retest pouzdanost te diskriminantnu valjanost upitnika.
\end{abstract}

Ključne riječi: lutanje uma, validacija, hrvatski prijevod MWQ-a, učenici

Primljeno: 12. 2. 2020. 


\section{Appendix 1}

\section{Mind-Wandering Questionnaire (Mrazek et al., 2013)}

\section{Upitnik lutanja uma}

Croatian translation

1. Teško se koncentriram na jednostavne ili jednolične zadatke.

2. Tijekom čitanja događa se da ne razmišljam o tekstu te ga stoga moram ponovno pročitati.

3. Nisam u potpunosti usredotočen/a na ono što radim.

4. Događa mi se da slušam jednim uhom, a istovremeno razmišljam o nečemu posve drugom.

5. Misli mi lutaju tijekom predavanja ili prezentacija. 
